\title{
Bennelong in Britain
}

\author{
Kate Fullagar
}

Bennelong's two-year stay in Britain, from 1793 to 1795, is an often-mentioned but little-studied event in the life of one of Australia's most significant Aboriginal ambassadors. Arthur Phillip recorded his hope to take Bennelong to Britain as early as 1791, writing to his long-time friend, Sir Joseph Banks, that if he does make the voyage 'much information [will then] be obtained for he is very intelligent'. ${ }^{1}$ Bennelong himself may have imagined his travels even earlier. By 1791 he knew enough about the British need for Indigenous informants to expect a long and adventurous relationship with the newcomers.

Although Bennelong was said upon departure to understand the rigours of the voyage ahead of him, he may not have been as prepared for the experiences that lay ahead in Britain. ${ }^{2}$ During his stay, Bennelong lived at a number of addresses, toured key sites like St Paul's Cathedral and the Tower of London, visited museums, attended theatre performances, enjoyed urban spas, and even took in a session of the trial of Warren Hastings at the Houses of Parliament. About one year into his residence, Bennelong's fellow Aboriginal travelling companion, the teenaged Yemmerawanne, died from a chest infection. Bennelong shouldered the supervision, and grief, of Yemmerawanne's burial, after which he evidently felt it was time to go home. He finally managed to secure a berth back in February 1795, docking at Port Jackson in September - nearly three years after leaving his homeland.

Historians have generally divided into two camps when they mention Bennelong's overseas sojourn. They split between those who claim it was an instance of patronising celebration and those who declare it was more an example of gross exploitation. ${ }^{3}$ All, however, assume that Bennelong's presence in Britain had a substantial impact. This article looks again at the impression that Bennelong was supposed to have made on British society. It finds that when compared to similarly-understood visitors in the eighteenth century, Bennelong attracted remarkably little attention. Relative to Indigenous travellers from other parts of the New World who had arrived in earlier decades, Bennelong stirred next to no interest from British authorities, dignitaries, or ordinary folk.

A study of his comparative lack of effect offers at least two advantages to history. First, and somewhat ironically, it promises an escape from the tragic

1 Phillip to Banks, 3 December 1791, Banks Papers, Mitchell Library, Series 37.12-20.

2 Collins 1975[1798-1802] I: 211.

3 In the first camp, see Clendinnen 2003: 264 and Langton 2008: 16, 29. In the second camp, see McBryde 1989: 23 and Maynard 2005: 202. 
narrative that is typically accorded Bennelong in contemporary scholarship. Most historians still insist that Bennelong's fate was a tragedy - either despite the attentions received in Britain or because of them. The discovery of inattention opens up a more pragmatic view: it frees Bennelong from a reduction to his reception alone, which was mostly beyond his personal control, and instead allows him a travel experience that was as mixed as any other. Far from constituting an even darker perspective on Bennelong than currently pertains, a history of his 'non-impact' in Britain reminds us of a life that was larger than whatever any outsider nation thought him.

Second, the study of an unexpected break in a convention casts light on the nature of that convention. In this case, Bennelong's ill-noticed visit reflected an important shift in British attitudes to Indigenous travellers from the New World. Such attitudes had for long been imbricated in more general views about Britain's right to expand its empire around the globe, and indeed had been the key driver in shaping the way previous New World visitors had been treated. Thus, Bennelong's minimal reception signalled a change in overall metropolitan imperial ideology.

\section{First encounters}

The early years of the colony at Port Jackson amount to the best-known episode of Bennelong's life. His abduction, incarceration, later escape and eventual peace negotiations with the First Fleeters have been recounted numerous times, by eyewitnesses and by later chroniclers and biographers. ${ }^{4}$ Few, however, have related how closely these events echoed earlier scenes between British colonists and other Indigenous people from the New World - namely, Native Americans and Pacific Islanders. Phillip's instructions to 'endeavour by every means possible to open an intercourse with the natives, and to conciliate their affections' emerged from centuries of British engagement with the New World. ${ }^{5}$ George III's Home Secretary, Lord Sydney, was well aware of the approaches of Walter Raleigh on the east coast of North America, for example, and of James Cook in Tahiti and elsewhere, where particular native informants had been sought and cultivated for information, cooperation and land purchases, had proved the most advantageous in unknown places.

Initially, Phillip had tried to 'cultivate our acquaintance' by peaceful means. ${ }^{6}$ The patent failure of this plan had led, first, to the abduction of Arabanoo, and then, after Arabanoo's unfortunate and quick death from smallpox, to the capture of Bennelong and Colebee. Elizabeth Macarthur later explained that by the time of this last event the Governor was in despair over ever achieving

4 The most cogent recent account, in my view, is Keith Vincent Smith's Bennelong. My own narrative of these years in Bennelong's life relies most heavily on Smith. See also Atkinson 1997 and Karskens 2009.

5 Crown to Phillip, 35 April 1787, Historical Records of New South Wales [hereafter HRNSW] 1892: 89-90.

6 Bradley 1969: 68. 
native confidence 'by fair means', so 'ordered that two men should be taken by force'. Though Macarthur believed that Bennelong and Colebee were soon awed by the civilisation now opened to them, she also conceded that the process of obtaining their acknowledgement had induced 'the Strongest marks of terror and Consternation'. ${ }^{7}$ The lieutenant in charge of the capture in November 1789 also remarked on its horror. The 'crying \& screaming of the women and children', admitted William Bradley, 'together with the situation of the two miserable wretches in our possession was really a most distressing scene; they were much terrified'. Bradley added that 'it was by far the most unpleasant service I was ever ordered to Execute' ${ }^{8}$

The subsequent story of Bennelong and Colebee's relationship with the colonists resonates partially with the story of Manteo and Wanchese's entanglements with Raleigh's colonists in sixteenth-century Virginia. It is not certain how Raleigh's captain, Arthur Barlowe, initiated relations with the two Algonquian men who later accompanied him to England to meet Raleigh, but the first, Manteo, remained a close contact for the eventual settlers of Roanoke while the second, Wanchese, spurned the British and devoted the rest of his life to their defeat. ${ }^{9}$ In like fashion, Bennelong - though he may have tried to run at first - soon came to discover the benefits of alliance with the newcomers while Colebee broke free of his irons within days of capture and remained a wary observer of British developments. ${ }^{10}$ Bennelong as native informant thus joined the ranks of Indigenous people in the New World who had concluded that maintaining links with newcomers was a safer and perhaps more prosperous route than closed-off rebellion.

Though his own shackle remained for a few more months, Bennelong swiftly became, in the view of the colonists at least, a cheerful and amenable resident of Government House. Various officers commented on his liveliness and intelligence, his humour and good nature, and his 'scrupulous' attendance to many forms of British etiquette. ${ }^{11}$ As a way of assimilating British hierarchy into something more familiar, Bennelong started to call Phillip beanga or father and referred to himself as Phillip's doorow or son. ${ }^{12}$ In exchange, it is clear that Bennelong expected both to achieve personal advancement among his own people and to instruct the British about the subtleties and predicaments of Eora society. Bennelong was an initiated though somewhat junior warrior of the Wangal clan who appeared eager from the start to enhance his position with his kinsmen by bringing them British gifts or by conveying warnings about the newcomers' doings. Numerous times during his first six months of residence with Phillip, Bennelong also tried to explain the complexities of tribal affiliation and place-naming within the Eora, as well as the devastation that smallpox had

7 Macarthur to Kingdon, 7 March 1791, HRNSW 1892: 502.

8 Bradley 1969: 181-183.

9 On these two Algonquians, see Vaughan 2006: 22-29.

10 On Bennelong's initial attempt to escape, see Smith 2001: 40.

11 See, for examples, Fowell in HRNSW 1892: 373; King, 'Journal', 9 April 1790, Mitchell Library, MS C155.

12 See Tench 1793: 35. And see Smith 2001: 42. 
recently wrought on the whole population. ${ }^{13}$ In this way, Bennelong reminds us of the Raiatean, Mai, who befriended Cook in Tahiti in 1773: Mai had sought an alliance with the recent arrivals not only as a way of embellishing his second-tier status in Raiatean society but also as a means of avenging Raiatean removal to Tahiti by nearby Boraborans. ${ }^{14}$

Yet like Manteo and Mai before him, Bennelong never lost his independent spirit. Suddenly, in May 1790, Bennelong jumped the paling fence around Government House and walked away from his new ties. No particular event appeared to have precipitated the escape; Bennelong may have been motivated by some unrelated local issue or, perhaps, by a desire to keep Phillip on his diplomatic toes. Phillip allowed himself a moment of philosophic reflection when he commented in a letter to Banks that 'our native has left us, \& that at a time when he appeared to be happy \& contented ... I think that Mans leaving us proves that nothing will make these people amends for the loss of their liberty' ${ }^{15}$

Bennelong remained secluded from the British for over three months. Then, in September 1790, he was sighted again by some officers at Manly Cove, evidently down on his luck, appearing emaciated and somewhat disfigured. Phillip joined the officers for the reunion. Bennelong was said to greet the Governor warmly and call him beanga once again. But Bennelong was also careful to orchestrate the meeting to his favour, arranging for nearly 20 fellow Eora to surround the pair while they conversed. At length, Bennelong gestured towards another Aboriginal man some way off, introducing him to Phillip as one of his 'very intimate friends'. Before Phillip could shake his hand, the man had grabbed a particularly long spear and hurled it into the Governor's shoulder. ${ }^{16}$ Most later historians, following the lead of most of the British commentators present on the day, have assumed that Bennelong was as shocked and mortified about the spearing as Phillip's fellow officers. Keith Vincent Smith, though, has proposed that Bennelong was rather the mastermind behind the affair: knowing that Phillip would want to be present for any reunion between them, he had time to arrange for a ritual and public punishment of the Governor for his earlier capture and other past wrongs by the British. In so doing, he erased the historical slate between the two groups at the same time as he recovered some of his apparently lost authority before kin peers. ${ }^{17}$

Bennelong's resurrection to power was no more obvious than in the peaceful coming-together of natives and newcomers that followed the events at Manly. From October 1790, more and more Eora people came into the British settlements for varying periods of time to share food, words and manufactures. The Aboriginal

13 See Phillip to Sydney, 13 February 1790, HRNSW 1892: 308; Hunter 1793: 531; Collins 1975[17981802] I: 137. See also Atkinson 1997: 157.

14 See Turnbull 2001.

15 Phillip to Banks, 26 July 1790, Banks Papers, Mitchell Library, Series 37.12-20.

16 See Tench 1793: 58; Smith 2001: 53-57.

17 Smith 2001: 57-59. Note that Clendinnen also made this point, though two years after Smith: Clendinnen 2003: 110-132. For an even more recent, though somewhat more sceptical, reflection, see Jones 2007: 41-42. 
elders had witnessed Bennelong restore justice to his personal relations with the British and demonstrated, through his confidence in Phillip's reluctance to issue reprisals, that the benefits of alliance with the British could outweigh the costs. As Smith notes, Phillip's magnanimity should not be forgotten here for the part it played in devising bicultural coexistence - however short-lived. ${ }^{18}$ 'From this time', recalled Watkin Tench in later years, 'our intercourse with the natives, though partially interrupted, was never broken off. We gradually continued, henceforth, to gain knowledge of their customs and policy.'19

Coexistence, of course, did not mean unmitigated amity. Violent skirmishes continued on occasion, and Bennelong himself often vacated Government House without warning for weeks at a time. But there was now a conversation in progress that could be taken up after leaving off at any time with reasonable assurance of good will from both sides. For the next two years, Bennelong was joined at the settlements by many Eora, and especially by younger men who were not yet or only recently initiated warriors. One of these young men was a teenager called Yemmerawanne. Also of Bennelong's Wangal clan, he was said by Tench to be a 'slender fine looking youth ... good tempered and lively', who served as an occasional servant at the Governor's table. ${ }^{20}$ The colony's Secretary, David Collins, later asserted that Yemmerawanne was 'much attached' to Phillip, which explained why he also accompanied the Governor to Britain in 1793. Possibly, the youth was instead a favourite of Bennelong, or, indeed, a kind of Bennelong-in-the-making, who gained a berth from his own entrepreneurial manoeuvrings. Whatever the rationale for his later journey, Yemmerawanne was, like his more senior clansman, an example of the free, independent and carefully tended Aboriginal person who now often mixed with the British.

As necessary as they were to the British, however, the Eora never fully escaped the intellectual straitjackets that the newcomers brought with them concerning New World people. No amount of conversing, it seemed, was enough to break some traditions. Every major colonial commentator of those early years referred to the Aboriginal people most typically as 'savages', following a connection made between New World lands and their Indigenous inhabitants as long ago as the sixteenth century. ${ }^{21}$ It is important to note that 'savagery' in the eighteenth century was a more capacious and generous idea than it became in the nineteenth century. ${ }^{22}$ Chiefly defined by judgements regarding social complexity, savagery was reckoned at this time to be the most simple mode of human collectivity. ${ }^{23}$ Not yet fully absorbed into stadial theories of human progress, though, such simplicity could be valued positively as often as it was negatively. James Boswell, for instance, wondered more than once whether savages were not 'happier' than

18 Smith 2001: 67.

19 Tench 1793: 71.

20 Tench 1793: 62-67, 86. Smith conjectures that Yemmerawanne may have introduced himself with the words: 'jam ora wanne', meaning 'my country is wanne [wangal]', Smith 2001: 97-98.

21 See Ellingson 2001: xiii; Hudson 1996: 249.

22 Sankar Muthu has recently reminded us of the obvious: that any appellation of savagery was 'ultimately dehumanising', Muthu 2003: 12.

23 Hodgen 1964; Meek 1976. 
contemporary Britons, even voicing a wish to live among them in the 'South Seas' for a while to taste their superior ways. ${ }^{24}$ Boswell's famous biographical subject, Samuel Johnson, on the other hand, held the better-known view of savagery. 'Don't cant in defence of savages', he scolded his friend, 'savages are always cruel [and] one set of Savages is like another ... What could you learn [in the South Seas]? What can savages tell, but what they themselves have seen? Of the past, or the invisible, they can tell nothing. ${ }^{25}$

In spite of their own observations of social sophistication among the Aboriginal people at Port Jackson, the early colonial commentators all insisted that these Indigenes also fitted within their received model of New World people - and they, too, were split in their evaluation of Eora savagery. While later Governor, John Hunter, and free settler, Daniel Paine, for examples, considered savagery a bestial condition that was 'irrational', 'ill-formed', and 'destitute', officers such as King, Collins, and Phillip himself, romanticised the state as one of nature, innocence and childlike youth. ${ }^{26}$

It was, then, paradoxically, as both recognised diplomat and essential savage that Bennelong boarded HMS Atlantic with Phillip on 10 December 1792. Accompanying the two leaders was Yemmerawanne, a couple of freed convicts, four kangaroos and several dingos. ${ }^{27}$ Though Collins noted that at the moment of their departure both Bennelong and Yemmerawanne had to field the 'united distress of their wives, and the dismal lamentations of their friends', the Aboriginal travellers themselves seemed relaxed and cheerful. ${ }^{28}$ They understood the journey ahead of them as the next chapter in their story of political and personal negotiation with a people who looked more and more likely to become permanent contenders in their lands. For their part, the British returnees were carrying out a tradition of escorting New World Indigenes to imperial centres that had been in effect since $1501 .^{29}$

The Atlantic set sail at first light the next morning, clearing the harbour heads by eight o'clock. Collins believed that the vessel was in good enough condition to hope for a speedy voyage of no longer than six months. ${ }^{30}$ True to estimate, the voyagers disembarked at Falmouth on 19 May 1793.

24 Boswell 1949[1791] I: 358, 1949 II: 33-34.

25 Boswell 1949[1791] II: 34, 532.

26 Hunter 1793: 502; Paine cited in Williams and Frost 1988: 197; King, 'Journal', 9 April 1790, Mitchell Library, MS C155.

27 Collins 1975[1798-1802] I: 211.

28 Collins 1975[1798-1802] I: 211.

29 Arguably the first such escorting had occurred in 1501 when some Bristolian fishermen had brought three Beothuk from Newfoundland to meet Henry VII. See Quinn 1979: 103.

30 Collins 1975[1798-1802] I: 211. 


\section{A history of absence}

Within days, the party was in London. Lloyd's Evening Post announced the arrival in a lengthy paragraph:

Governor Philip [sic] has brought home with him two natives of New Holland, a man and a boy, and brought them to town. The Atlantic has also on board four kangaroos, lively and healthy, and some other animals peculiar to that country. From the description given of the natives of Jackson's Bay they appear to be a race totally incapable of civilization, every attempt to that end having proved ineffectual ... no inducement, and every means have been perseveringly tried, can draw them from a state of nature ... They are cruel, particularly to their women, whom they beat in a most barbarous manner on every occasion. That instinct which teaches to propagate and preserve the species, they possess in common with the beasts of the field, and seem exactly on a par with them in respect to any further knowledge of, or attachment to kindred. ${ }^{31}$

The author of this piece clearly took the Johnsonian line on savagery. In retrospect, however, the most startling aspect of the account was its singularity. Though repeated verbatim by the Dublin Chronicle a few days later, no other newspaper commented on the Aboriginals' presence in Britain for the next 21 months.

The extraordinariness of this absence can only be gauged by comparing it with the impact made by some earlier New World envoys. The first properly popular visit by so-called savages occurred in 1710 when four Native Americans from Iroquoia came to argue for military assistance against French encroachment into their lands. Though Native Americans had travelled to Britain for over two centuries, the four Iroquois were the first to inspire fascination at all levels of society - from courtiers to bishops to merchants to artists to plebeians on the street. Everywhere they toured, crowds were said to materialise just for the chance to witness a supposedly pristine embodiment of savagery. Their movements were traced in all the major urban publications; their images were drawn by various artists; and their presence was requested at theatres, taverns and other public venues. When seven Cherokee turned up in 1730 to broker a treaty for preferential trade, they were similarly hounded, reported, depicted and desired. Likewise, when another envoy of Cherokee arrived in 1762, some estimated the mobs surrounding them to reach 10,000 or more. The same attention clung to every significant arrival by Native Americans until around 1770, when Pacific Islanders took over as the ideal embodiment of savagery. Mai's arrival in 1774 caused the greatest stir of all, inspiring pantomimes and epic poetry as well as the now usual squibs, prints, portraits and odes. ${ }^{32}$

Just as Pacific Islanders were elided with Native Americans in most British imaginaries by the third quarter of the eighteenth century, so Australian

31 Lloyd's Evening Post, 29 May 1793.

32 For a synthesis of all these visits, see Fullagar forthcoming. For individual accounts see Bond 1952; Steele 1977; Oliphant 1999; McCormick 1977. 
Aboriginals were said to fit the model of New World savagery when they were encountered in the same decades. What bound all together was, first, British understandings of geography and, second, British determinations about what kind of person inhabited certain geographies. Following the European voyages of re-discovery to the Pacific from the 1760s, the Antipodes were called variously the 'terra incognita of America' or the 'Southern Part of the New World'. ${ }^{33}$ As New World folk, Antipodeans instantly joined Native Americans as paradigmatic savages. More than any other group who has borne the ignominious title in the past, New World people were considered archetypal savages during the eighteenth century - mostly because they were understood first and foremost in social terms. Their supposedly simple social system - decided with little debate for all peoples from Newfoundland to New Zealand - was what most compelled Old World commentators. It was also thus what most adhered in their categorisation, distinguishing them from those who were more often identified in this age by barbarism, say, or by bondage. ${ }^{34}$

Bennelong and Yemmerawanne, thus, surely fitted the British definition of 'New World savages' at this time and, as the first Australian Aboriginals to arrive in Britain, should have inherited the tradition of fascination that had emerged around such types over the last 80 years. Their lack of impact, therefore, appears a historical anomaly (though it bears remarking here that historians can hardly be disappointed to find their subjects escape this particular kind of attention). As a keen student of eighteenth-century British activity in the New World, Phillip patently believed that his charges would attract as much scrutiny as had their predecessors - whether welcomed or not. It is evident from the manner of his various arrangements for the Aboriginals that he expected a certain level of gawking. In every case, however, those expectations proved unfounded.

First, most previous New World envoys had inspired gossip about their place and mode of lodging while in Britain. Readers were amused to learn that the four Iroquois of 1710, for example, had never before slept in a bed, and many waited outside their Covent Garden address to ask them how they had found the experience. They were even more tickled when the Cherokee of 1730 stayed in the same West End home, one newspaper even assuming that it had been recommended to them by their 'neighbouring' countrymen. ${ }^{35}$ Yet, though

33 See, for examples, Guthrie 1770; Cooke 1800; Pinkerton 1802.

34 Other peoples at this time were of course labelled as savage too. But it is arguable that these others were primarily categorised by an alternate property, such as barbarism in Asians or bondage in Africans. It is indeed further arguable that the appellation of 'savage' in these cases was more often used as a loose synonym for that alternate property than it was a proper reference to a simple social state. To paraphrase an elder authority on the history of name-calling, savagery 'never seemed to be as important a quality' in Asians or Africans as it was in the New World person: Jordan 1969: 27. For these reasons, the presence of Asians and Africans in Britain at this time occasion a case for interesting comparison rather than any serious complication to my thesis. For a longer discussion of all these points, see Fullagar 2009.

35 The Tatler, 13 May 1711; The Daily Courant, 3 August 1730. 
Bennelong and Yemmerawanne also stayed in a West End residence for much of their stay, no remark was ever made of it - there was no speculation of footsteps retraced nor any joke of beds once more tried anew. ${ }^{36}$

Second, all earlier delegates had attracted crowds whenever they toured the key sites of London. Observers reported 'throngs', 'concourses', 'rabbles' and 'gaping multitudes' surrounding New World people who visited St Paul's Cathedral, the Tower arsenal, Woolwich docks, Exchange Alley and the Houses of Parliament. ${ }^{37}$ The Cherokee delegation of 1762 caused such a 'press' of people at Vauxhall Gardens that they were forced to retire, fuelling bitter discussions in the papers about 'wretched scene[s] of British ... Debauchery'.$^{38}$ Phillip set Bennelong and Yemmerawanne on a similar itinerary to their predecessors designed no doubt, as for these earlier envoys, to impress and beguile - but they in contrast were never noticed by passers-by. No-one even remarked on the seeming piquancy of the Aboriginals' visit to the Parkinson Museum, which famously housed artefacts from Cook's three Pacific voyages, or on their presence at the trial of one-time imperial governor, Warren Hastings, which otherwise made the news for all 148 days of its progress. ${ }^{39}$

Third, like some of their more recent precursors, Bennelong and Yemmerawanne were assigned a language tutor to help advance their English. ${ }^{40}$ But unlike Mai from Raiatea or Lebuu from Palau, for example, whose similar lessons occasioned fierce debate about both the morality and efficacy of British legacies to New World visitors, the Aboriginals stirred negligible discussion either way. ${ }^{41}$ As with the earlier-arrived Polynesians, Bennelong and Yemmerwanne were thought by later acquaintances not to have profited very much by their tutorials, but again no comparison - cynical or otherwise - was ever made.

Fourth, Yemmerawanne's death in May 1794 also had some firm precedents. When a member of a Creek envoy in 1734 died in Westminster, and again when Lebuu died 50 years later in Rotherhithe, British commentators went into rhetorical overdrive. The 1734 Creek death provoked various sarcastic investigations into Native American burial rituals while Lebuu's death solicited a more sentimental or proto-romantic mourning. ${ }^{42}$ Both instances, however, stood out as noteworthy events. Yemmerawanne sickened with a mysterious ailment for over five months, requiring the administrations of laxatives, blisterings,

36 From July 1793 to October 1793 and then again from November 1793 to May 1794 the Aboriginals boarded with William Waterhouse - father of Lieut. Henry Waterhouse of the First Fleet - in Mount Street, Grosvenor Square. Treasury Board Papers, Public Record Office [hereafter TBP, PRO], T1/733.

37 See for examples Dawks' News Letter, 29 April 1710; The Universal Spectator, 12 September 1730; The Spectator, 19 May 1711; St James' Chronicle, 31 July 1762.

38 St James' Chronicle,31 July 1762.

39 Brook offers a neat summary of the Aboriginals' touring, gleaned from the bills of expenses extant in the Public Record Office, Brook 2001: 38-41.

40 TBP, PRO, T1/733.

41 See McCormick 1977: 165, 258, 290; Keate 2002: 260.

42 See Vaughan 2006: 158; Keate 2002: 265-268. 
draughts and pills, but in that time attracted neither quipster nor elegist. ${ }^{43} \mathrm{He}$ died on 18 May 1794, earning a respectable funeral at Eltham Parish Church and an entry in Eltham's Parish burial registry. Phillip ensured that the Crown paid for his modest tombstone, still evident in Eltham's churchyard, even if he could not summon public pause over the death in any form. ${ }^{44}$

A final point of comparison between the Aboriginals' visit and previous visits is their access to royalty. Every significant New World envoy before Bennelong had at least one audience with the reigning monarch of the day. The British bureaucrats surrounding each delegation - no matter how informally some had begun - knew it was crucial to legitimate any agreement they wished to make with these potential allies with a ceremony of introduction to the highest office in the land. For their part, eighteenth-century monarchs generally welcomed the idea of meeting figures who had proved such popular icons among their subjects - none, of course, was immune to the cultural forces that had made New World people so intriguing in this period. The royal audience, indeed, was usually the best recounted episode of any visit. As today, the fantasy of royalty made excellent press for the popular periodicals. And also like today, monarchs in the eighteenth century were highly accountable creatures: their every movement was recorded daily in public court chronicles.

Bennelong and Yemmerawanne were the first New World envoys in the century not to meet the monarch. Most historians of the matter have claimed that they did. It is perhaps the single most common statement made in today's cursory one-line descriptions of Bennelong's travels: that he 'was taken to London to see the King', ${ }^{45}$ But this turns out to be a narrative that supports modern opinions about the nature of Bennelong's impact in Britain, rather than one based on evidence. No mention exists in George III's extensive archive; no newspaper gossiped about such a meeting; and none of the court chroniclers of the time - which in this decade included the Times and The Annual Register - even suggested the possibility. ${ }^{46}$ It seems patent that Phillip intended for his charges to attend St James' Palace, since he made sure - like most British escorts had before him - to have Bennelong and Yemmerawanne outfitted at a tailor's within days of arrival. ${ }^{47}$ Their subsequent purchases - of silk stockings, blue and buff striped waistcoats, and slate-coloured ribbed breeches - would have been more than fine enough for a king, but it seems that they never earned quite so lofty an audience.

43 See Brook again on the medical details deducible from the bills. Brook 2001: 40-42.

44 TBP, PRO, T1/733.

45 Clendinnen 2003: 264.

46 See discussions by the first Bennelong historian to question the royal meeting - Brodsky 1973: 65. My own hunt confirms the absence of reports. Brodsky believes that the historical consensus arose from a claim made in a Port Jackson soldier's 1803 published account. If so, it gained currency without acknowledging the part that such a claim served in the soldier's broader argument about the wilfulness of Bennelong to return to savagery despite all the 'comforts' of civilisation shown him. See Bond 1803: 6 .

47 TBP, PRO, T1/733. And see Brook 2001: 38. 
The lack of royal encounter, along with all the other instances of inattention shown Bennelong and Yemmerawanne during their visit, signified a key change in the reception of New World peoples. ${ }^{48}$ While the visiting Aboriginals fitted the British image of paradigmatic savagery in every other respect, they defied the convention of becoming mini-celebrities during their stay. As implied before, it would be perverse to register this as any failure on the visitors' part. Indeed, their escape from public scrutiny no doubt afforded them the time and space to enjoy, or dislike, their experiences in Britain as deeply as would any private person. But the absence did mark something unusual: if Bennelong and Yemmerawanne were accorded the status of savages, either the meaning or the effect of this label must have transformed by the 1790s.

\section{Savagery transformed}

The 1790s were, of course, a particularly distracting decade in Britain. It could be argued that Britons were too wrapped up in their current French Revolutionary wars to notice the latest arrival of a New World savage. ${ }^{49}$ Except, most other New World envoys in the eighteenth century had also arrived in time of war: the War of Spanish Succession (1701-1713), the Seven Years War (1756-1763) and the American Revolutionary War (1775-1783) were in the background of several earlier visits and had never detracted from the interest shown in them. Moreover, Londoners in 1793 were not so distracted that they ignored the four kangaroos that had come with the Aboriginals. Hundreds swarmed to view the one on display in the Lyceum Museum in the Strand. On show every day from eight in the morning till eight in the evening, for the not inconsiderable price of a shilling, the museum was hesitant to give too much away:

to enumerate [the animal's] extraordinary Qualities would far exceed the common Limits of a Public Notice. Let is suffice to observe that the Public in general are pleased, and bestow their Plaudits; the ingenious are delighted; the Virtuoso, and Connoisseur, are taught to admire! ${ }^{50}$

One reader of the popular Gentleman's Magazine was evidently tantalised to extremity. Unable to get to the Lyceum himself, he wrote a letter to the editor asking if he had 'no kind friends ... that will give you some account ... of the

48 This inattention can be said to have continued for nearly three generations, before New World visitors became popular again - in almost entirely negative ways - from the 1880s. Roslyn Poignant's 2004 account of the Aboriginal people who travelled to Britain as part of RA Cunningham's spectacle business in the 1880s shows how such people were now fascinating for the way they fit into positivist views of race rather than as exemplars of a simple society. The definition of savagery - not just its function - had changed dramatically, becoming a sign of science rather than of political theory. The first Aboriginal cricket team to tour Britain in 1868 was not a profoundly popular phenomenon, though the interest they did attract was no doubt a precursor to the scientific thinking behind the interest in the later Aboriginal circus acts rather than a remnant of enlightenment views (see Mulvaney 1967).

49 Hiatt offers this argument, 2004: 88-89.

50 Lyceum Museum Broadside, Mitchell Library (reproduced in Williams and Frost 1988: 201). 
gamgarou, the new animal just brought to England from South Wales by Governor Phillip. Certainly, Sir, it would give much satisfaction ... to be informed of the ... creature. ${ }^{51}$

It could also be argued that personal reasons accounted for Bennelong's neglect: Bennelong did not appear a prince as had many earlier New World visitors; Bennelong was too acculturated to British ways to stand out as different. Neither conjecture, however, absorbs the full impact of his visit's precedence. Britons were more than aware that several earlier delegates had not been princes - the Cherokee of 1730, for instance, were barely acknowledged as competent officials. Certain earlier delegates, too, had experienced even more contact than had Bennelong - the Iroquois had been negotiating with colonial newcomers for nearly three generations by the time their representatives travelled in 1710 . Bennelong's pedigree and demeanour had been sufficient to attract the attention of the First Fleeters so could reasonably be expected to do the same in Britian.

Thus, it was something about the supposed savagery of Bennelong, rather than any particular circumstance or individual trait, that no longer pertained in 1790s Britain. To understand this change, we need to grasp not only the existence of greater fascination for earlier New World envoys but also its content. Why had Britons been so intrigued by savage visitors before 1790? What had they actually said in their myriad reports of their daily activities around London? As I have argued elsewhere, most discussion surrounding New World envoys from 1710 to around 1785 can be said to revolve around a single theme: the recent explosion of Britain's commercial reach into precisely those lands from which the delegates had come. Entailed in this discussion was the attendant complication of domestic social and cultural relations. ${ }^{52}$ The simplicity accorded the delegates turned out to be one of the most powerful stimulants to the debate on Britain's conversely complex society. Savagery in its embodied form was peculiarly potent because it seemed to work for all sides in the contest: it was mobilised in defences of British expansion as often as it was for attacks, and within each camp it could work either sympathetically or antagonistically. The flexibility of the concept in this era is what made it so especially 'good to think' ${ }^{53}$

For example, when the four Iroquois visited in 1710, commentators used them in different ways to make different polemical statements about the effect of expansion. One pamphlet noted admiringly that 'these princes do not know how to cocker and make much of themselves', which for the author contrasted alarmingly with the manners that 'our Luxury [now] brings upon us' ${ }^{54}$ Another popular squib agreed that Britain's new fortunes had engendered a dangerous

51 Gentleman's Magazine, 1793: 531.

52 See Fullagar forthcoming.

53 The term 'good to think' was coined by Claude Levi-Strauss. Its awkwardness was deliberate, since it was intended to play on the more common idea of something being 'good to eat'. LeviStrauss argued in Totemisme that 'natural species are chosen [as totems] not because they are "good to eat" but because they are "good to think"': see translation in Levi-Strauss 1963[1962]: 89.

54 Anon 1710b: 7. 
decadence, but rejected the contrastive model: it believed that Britons now suffered an empty culture just like savages always had in the New World. 'Since no one brought less', it quipped, 'of Wealth, Knowledge, or Dress / Than those who from [American] India are come.' But 'no one before', it concluded, has 'Return'd from our Shore / With so little advantages Home. ${ }^{\prime 5}$ On the other end of the debate, the famous essayist, Richard Steele, praised Iroquoian savagery as a way of praising Britons. He believed that the Iroquois would feel at home in London since their innate 'generosity' and 'dignity' - borne of their minimalist condition - complemented the politeness and civility spawned by advanced commerce. ${ }^{56}$ A popular ballad at the time gave the fourth variation on the theme: it attacked savagery as a means of congratulating British accomplishment. The Four Indian Kings Garland was a love story about an Iroquois who falls for an English maiden but who can never succeed because he is of a 'sad condition' and she is of the 'boldest' state on earth. ${ }^{57}$

In every significant delegation following, the same kinds of response emerged. When the Creek Tomochichi arrived in 1734 to secure fair race relations within the new colony of Georgia, his presence occasioned one poet to rhapsodise over his 'wond'rous form', so 'uncloath' $\mathrm{d}$ and artless', which contrasted so damningly with a Britain now lost in 'soft luxurious ease', having sold its 'ancient virtue' to 'large commerce [and] wealth without end' ${ }^{58}$ The Caledonian Mercury, on the other hand, sniggered over the Creeks' lack of religion and language during the same visit, applauding them only for their capacity to admire Britain's 'grandeur ... riches ... and extensive trade and commerce', which together accounted for the British 'benevolence' shown the envoy. ${ }^{59}$

In 1762, when three Cherokee arrived to confirm their recent peace with Carolina traders, the debate over British expansion seemed only to have deepened. The London Chronicle was horrified to see the frenzy of gawkers whip up around the delegates, contrasting the calm of the 'savages' with the excesses of Britons, who apparently lacked decorum because of their economic insatiability and concomitant militarism: 'if we were not by commerce in pursuit of trifles round the globe', the paper declared, 'we should not need to station fleets in every part of it' $^{\prime 60}$ Other organs felt that the visitors themselves were to blame for the British frenzy. They pointed to the savages' intemperance and hypersexuality as the real cause for corrupting an otherwise 'fair' and 'courageous' people. ${ }^{61}$

The visit of Mai from 1774 to 1776 was perhaps the most famous instance of a New World envoy in the eighteenth century. Like his predecessors, Mai occasioned debate on British expansion from all approaches. The bestselling

55 Anon 1710c.

56 The Tatler, 13 May 1711.

57 Anon 1710a.

58 [Fitzgerald?] 1736.

59 Caledonian Mercury (Edinburgh), 1 November 1734.

60 The London Chronicle, 31 August 1762.

61 For intemperance, see St James' Chronicle, 31 July 1762. For sexuality, see Howard 1762. 
squib, An Historic Epistle from Omiah, pursued the especially popular prosavagery/anti-British line. A virtuous Mai asks if Britain can really 'boast, with all her pilfer'd wealth, / A larger share of happiness, or health?' ${ }^{\prime 2}$ Another satire of the times shared the Epistle's scepticism about British wellbeing but did not think savagery its opposite: the anonymous author of Transmigration chastised British economic success in the New World as 'simple FORNICATION', which for him put the nation exactly on par with Pacific societies. ${ }^{63}$ The apologist views similarly came from contrary positions on savagery. When the Reverend JE Gambier met Mai in 1774, he compared the 'strict \& rational temperance of this Savage' with the 'unaffected' and 'intrepid' abstemiousness of British people. ${ }^{64}$ The poet William Cowper, however, felt that Mai was an example of a pitiful, rude savagery - one that 'can boast but little virtue' in its easy inertness - which was for him most unlike Britain, where virtue flourished under a thriving culture. ${ }^{65}$

During most of the eighteenth century, then, the question of expansion - and more importantly its social and cultural effects - was very much on Britain's moral table. The embodied ideal of savagery had proved one of the major means of its popular analysis. Far from serving as a frivolous escape from some of the more vexing issues of the age, the fantasy of savagery provided Britons with a way of confronting, and dissecting, their various possibilities.

But this was clearly not the case by century's end. That Bennelong and Yemmerawanne did not receive the same treatment as their New World predecessors speaks of a profound shift in metropolitan discourse about British expansion, or at least about savagery's relationship to it. While many recent historians have investigated the transformation in British imperial style in this decade, fewer have attended to the change in rhetoric that accompanied it. In 1989, CA Bayly gave perhaps the most succinct account of the shift in style. His Imperial Meridian argues that in response to the 'world crisis' of the 1780s, which included not only the American Revolution but also the intimations of radicalism burbling in France and various local uprisings in Asia, Britain forged a newly 'despotic' practice of empire. ${ }^{66}$ Despotism involved both an aggressive political centralisation and a rigid social theory. Bayly's classic example of 'imperial despotism in miniature' is, in fact, the colony of New South Wales after 1795, where increasingly authoritarian leadership together with progressively segregationist policy found reinforcement in the 'similar ... despotisms' sprouting all over Britain's global sphere of influence at this time. ${ }^{67}$ Bayly is less articulate about contemporary metropolitan views on this hardening, though - other than to declare that the British somehow discovered the 'ideological

62 Anon 1775.

63 Anon 1778.

64 Notebook of Reverend JE Gambier, 11 August 1774, cited in McCormick 1977: 102-103.

65 Cowper 1863: 48.

66 Bayly 1989: 11, 99. See, for similar arguments, Colley 1994; Marshall 2005.

67 Bayly 1989: 207-209. 
will' for their 'more vigorous world empire' when they needed it, and that the 'classical fear that empire necessarily corrupted civic virtue through luxury and decadence was already on the wane by the $1770 \mathrm{~s}^{\prime} .{ }^{68}$

What remains under-examined is the way that domestic discourse on British global activity underwent a major reorganisation of priorities in the late eighteenth century. It was not just the classical fear of imperial corruption that waned during this time but also its flipside of bravado about commercial redemption. The whole field of debate over whether or not Britain should build its empire had fallen away by the 1790s. In its place arose a new field of debate that was similarly riven with disagreements but which ran in an entirely new direction. Where previous discourse had centred on the right of empire to exist, the latter discourse centred on the question of best practice now that empire was established. It was a shift from fundamental to secondary questions; from issues surrounding contact to issues surrounding management.

This is not to claim that Britain now entered a period of consensus - it was after all the era of fiery contests over political, cultural and religious enfranchisement for British subjects wherever they lived in the world. Britons from late-century fought with as much energy as any earlier polemicist over the proper reach of missionaries, for example, or the kind of education that colonial offices provided, or the degree to which self-government could be entertained in the dominions. But these disagreements were categorically not debates over the question of imperial presence per se. The secondary concerns regarding the building of empire had swamped any sense that Britons should continue to debate the more fundamental question of whether they should engage in empire-building at all.

In the former discourse, savagery had been an eloquent tool for analysis. As a sign of radically simple society, it offered a useful means for thinking about the consequences of increasing complexity that was said by all to follow expansion. It helped Britons to ask themselves whether or not greater trading advantage around the world, with its consequent boost to wealth and sophistication, was what they truly wanted for their nation.

The latter discourse based on secondary questions, however, seems to have had less use for the concept. It is of course always fraught to argue a case from absences, but given the myriad comparisons, it is possible to conjecture that from about 1790 savagery gradually lost its appeal. A notion of social simplicity just did not seem as salient to a debate about how things could be better as it had proved to a debate about whether things should actually emerge at all.

\section{'At home now'}

Bennelong's neglect in Britain has been overlooked until now due to a lack of comparative approach. Historians have seen the kindly condescension or

68 Bayly 1989: 99, 138. 
repugnant abuse that they expect to see because they have never seriously studied Bennelong in any context larger than that of Sydney's first four years. Only when understood as the latest version of New World savagery to arrive on British shores does Bennelong's dismissal by the locals start to look noticeable and simultaneously strange. The investigation into how Bennelong fitted a larger context but missed its conventional procedures uncovers a critical change in Britain's domestic attitude towards New World indigenes. This, in turn, uncovers a critical change in the metropolitan outlook on empire itself. Bennelong's lack of appeal as an embodiment of savagery spoke to a significant break with older concerns about imperial decadence and a new resolve to concentrate now only on imperial details.

Before Bennelong's voyage to Britain, Watkin Tench claimed to have imagined that his Aboriginal acquaintance would one day become something 'like a second Omai [Mai]', a noble savage taken back to the colonists' own country, destined to share the Polynesian's fate as 'gaze of the court and scrutiny of the curious' ${ }^{69}$ But Tench, like Phillip, turned out to be solidly a man of an earlier eighteenth century. He had been schooled in the early-modern history of British encounter with the New World and expected that the process of colonising Terra Australis would largely follow suit. Tench did not see that his own colony was swiftly becoming an instance of an entirely new brand of British expansionism, nor did he suspect that his countrymen back home would view their traditional native informants in entirely new ways.

It was to this changing colony that Bennelong returned in September 1795. His personal reaction - like that of many returnees from anywhere in any time - was a combination of swagger and confusion: he liked to show off his new clothes and ideas to his half-listening friends but was hurt to find his wife, Kurubarabulu, taken up with another man and that other kin relations had adjusted subtly in his absence. ${ }^{70}$

What Bennelong made of the tenser colonial politics at Sydney Cove is less clear. Perhaps the straightening attitudes of the new Governor, together with his greater intolerance of Indigenous difference, was what finally pushed Bennelong to leave the British settlement once and for all. Few of the early colonial commentators saw it this way, however. Even though David Collins admitted that relations between the societies at Port Jackson had deteriorated to 'open war' by the late 1790s, the now Judge Advocate claimed to be amazed at Bennelong's subsequent rejection of the British. 'This man', Collins wrote,

instead of making himself useful, or shewing the least gratitude for the attentions which he received from every one, [became] a most insolent

69 Tench 1793: 87.

70 Karskens gives a nice narrative. Karskens 2009: 422. 
and troublesome savage ... Instead of living peaceably at the governor's house, as he certainly might always have done, Bennilong preferred the rude and dangerous society of his own countrymen. ${ }^{71}$

Like Phillip and Tench before him, it seems, Collins could not appreciate the significance of the imperial toughening that was going on around him.

Yet as Bennelong's half-presence through the records of his journey reminds us, no one is ever entirely cognisant of, or indeed fully explained by, grand historical forces. At the level of everyday intimacy - which is surely the level at which Bennelong experienced most of his time in Britain, unencumbered by the consciousness of past precedence - the great waves of time break only intermittently. Bennelong's final word on his travels - the jaunty and solipsistic letter to his old carer back in Eltham - indicated as much. It read:

Sir, I am very well. I hope you are very well. I live at the Governor's ... I have not my wife; another black man took her away; we have had murry doings: he speared me in the back, but I better now ... all my friends alive and well. Not me go to England no more. I am at home now. I hope Sir you send me anything you please Sir. Hope all are well in England ... Bannolong. ${ }^{72}$

\section{References}

\section{Primary sources}

Anon 1710a, The Four Indian Kings' Garland, London.

- 1710b, The Four Kings of Canada, London.

- 1710c, The Royal Strangers' Ramble, London.

- 1775, Historic Epistle from Omiah to the Queen of Otaheite, London.

- 1778, Transmigration, London.

Bennelong to Phillips, 29 August 1796, Rex Nan Kivell Collection, manuscript 4005, National Library of Australia.

Bond, George 1803, A Brief Account of the Colony at Port Jackson, published by the author, Southhampton.

Boswell, James 1949[1791], The Life of Johnson, 2 vols, S Roberts (ed), J.M. Dent \& Sons Ltd, London.

71 Collins 1971[1798-1802] II: 7, 46.

72 Bennelong to Phillips, 29 August 1796, Rex Nan Kivell Collection, MS 4005, National Library of Australia, Canberra. 
Bradley, William 1969, A Voyage to New South Wales; The Journal of Lieutenant William Bradley RN of HMS Sirius, 1786-1792, facs reprint by the Trustees of the Public Library of NSW, Sydney.

Collins, David 1971[1798-1802], An Account of the English Colony in New South Wales: with remarks on the dispositions, customs, manners, Ec. of the native inhabitants of that country, to which are added, some particulars of New Zealand, vol 2, Libraries Board of South Australia, Adelaide.

- 1975[1798-1802], An Account of the English Colony in New South Wales: with remarks on the dispositions, customs, manners, Ec. of the native inhabitants of that country, to which are added, some particulars of New Zealand, vol 1, Reed in Association with the Royal Historical Society, Sydney.

Cooke, George 1800, A Modern and Authentic System of Universal Geography, C. Cooke, London.

Cowper, William 1863, The Poetical Works of William Cowper, William P. Nimmo, Edinburgh.

Crown to Phillip, 35 April 1787, Historical Records of New South Wales, 1892, vol 1, part 2, Government Printer, Sydney.

[Fitzgerald, Thomas?] 1736, Tomo Chachi, An Ode, London.

Guthrie, William 1770, A New Geographical, Historical, and Commercial Grammar, Dilly \& Robinson, London.

Howard, Henry 1762, A New Humourous Song on the Cherokee Chiefs, London.

Hunter, John 1793, An Historical Journal of the Transactions at Port Jackson and Norfolk Island, John Stockdale, London.

Keate, George 2002[1788], An Account of the Pelew Islands, KL Nero and N Thomas (eds), Leicester University Press, London and New York.

King, Philip Gidley 1786-1790, Journal, Mitchell Library, Sydney, MS C155.

Phillip to Banks, 3 December 1791, Banks Papers, Mitchell Library, Sydney, Series 37.12-20.

Pinkerton, John 1802, Modern Geography, Cadell \& Davies, London.

Tench, Watkin 1793, A Complete Account of the Settlement at Port Jackson, Nicol \& Sewell, London.

Treasury Board Papers, Public Record Office, T1/733. 


\section{Newspapers}

Caledonian Mercury, Edinburgh

The Daily Courant

Dawks' News Letter

Gentleman's Magazine

Lloyd's Evening Post, London

The London Chronicle

The Spectator

St James's Chronicle

The Tatler

The Universal Spectator

\section{Secondary sources}

Atkinson, Alan 1997, The Europeans in Australia: A History, Oxford University Press, Melbourne.

Bayly, CA 1989, Imperial Meridian: The British Empire and the World, 1780-1830, Longman, London and New York.

Bond, Richmond 1952, Queen Anne's American Kings, Oxford University Press, Oxford.

Brodsky, Isadore 1973, Bennelong Profile: Dreamtime Reveries of a Native of Sydney Cove, University Co-operative Bookshop Ltd, Sydney.

Brook, Jack 2001, 'The forlorn hope: Bennelong and Yemmerawannie go to England', Australian Aboriginal Studies 1.

Clendinnen, Inga 2003, Dancing with Strangers, The Text Publishing Company, Melbourne.

Colley, Linda 1994, Britons: Forging the Nation, 1707-1837, Pimlico, London.

Ellingson, Ter 2001, The Myth of the Noble Savage, University of California Press, Berkeley.

Fullagar, Kate forthcoming, The Savage Visit: Native Americans and Native Oceanians, 1710-1795, University of California Press, Berkeley. 
- 2009, 'Reynolds' new masterpiece: from experiment in savagery to icon of the eighteenth century', The Journal of Cultural and Social History.

Hiatt, LR 2004, 'Bennelong and Omai', Australian Aboriginal Studies 2.

Hodgen, Margaret T 1964, Early Anthropology in the Sixteenth and Seventeenth Centuries, University of Pennsylvania Press, Philadelphia.

Hudson, Nicholas 1996, 'From 'nation' to 'race': the origin of racial classification in eighteenth-century thought', Eighteenth-Century Studies 29(3).

Jones, Phillip 2007, Ochre and Rust: Artefacts and Encounters on Australian frontiers, Wakefield Press, Adelaide.

Jordan, Winthrop 1968, White over Black, University of North Carolina Press, Chapel Hill.

Karskens, Grace 2009, The Colony: A History of Early Sydney, Allen \& Unwin, Sydney.

Langton, Marcia 2008, The First Australians: An Illustrated History, Melbourne University Press, Melbourne.

Levi-Strauss, Claude 1963[1962], Totemisme, Rodney Needham (ed), Penguin, Harmondsworth.

Marshall, PJ 2005, The Making and Unmaking of Empires, Oxford University Press, Oxford.

Maynard, John 2005, 'Transcultural/transnational Interactions and Influences on Aboriginal Australia' in Connected Worlds: History in Transnational Perspective, Ann Curthoys and Marilyn Lake (eds), ANU E Press, Canberra, 195-208.

McBryde, Isabel 1989, Guests of the Governor: Aboriginal Residents of the First Government House, Friends of First Government House Site, Sydney.

McCormick, Eric 1977, Omai: Pacific Envoy, Auckland University Press, Auckland.

Meek, Ronald 1976, Social Science and the Ignoble Savage, Cambridge University Press, Cambridge.

Mulvaney, DJ 1967, Cricket Walkabout: The Australian Aboriginal Cricketers on Tour, 1867-8, Oxford University Press, Melbourne.

Muthu, Sankar 2003, Enlightenment against Empire, Princeton University Press, Princeton. 
Oliphant, John 1999, 'The Cherokee Embassy to London, 1762', The Journal of Imperial and Commonwealth History 27(1).

Poignant, Roslyn 2004, Professional Savages: Captive Lives and Western Spectacle, University of New South Wales Press, Sydney.

Quinn, David (ed) 1979, New American World: A Documentary History of North America to 1612, first volume, Macmillan, London.

Smith, Keith Vincent 2001, Bennelong: The Coming in of the Eora, Sydney Cove 1788-1792, Kangaroo Press, East Roseville.

Steele, William O 1977, The Cherokee Crown of Tannassey, John F Blair, WinstonSalem, N.C.

Vaughan, Alden T 2006, Transatlantic Encounters: American Indians in Britain, 1500-1776, Cambridge University Press, Cambridge.

Turnbull, Paul 2001, 'Mai, the other beyond the exotic stranger', in Cook E Omai: The Cult of the South Seas, Michelle Hetherington (ed), National Library of Australia, Canberra.

Williams, G and A Frost (eds) 1988, Terra Australis to Australia, Oxford University Press, Melbourne. 